Прегледни чланак

$347.7 / 8: 339$

doi:10.5937/zrpfns52-17040

Marija D. Mijatović, Ph.D., Legal Trainee

mrksicmarija@gmail.com

\title{
THE CURRENTNESS OF THE UNIDROIT PRINCIPLES OF INTERNATIONAL COMMERCIAL CONTRACTS - EFFECTS OF BOTTOM-UP METHOD OF LAW HARMONIZATION
}

\begin{abstract}
The UNIDROIT Principles of International Commercial Contracts have recently been published in their fourth edition, prompting the analysis of the origin of such a great success of this multifunctional instrument. Namely, this soft law regulation, although formally non-binding has significant de facto legal effects: it is a model law for many legal systems, it can be used as the law governing contracts, in processes before courts and arbitration tribunals, and as a means of interpretation and supplementation of uniform instruments. In this paper, the role of the so-called bottom-up approach was observed as an academic, non-sanctioned method of law harmonization that was applied in the making and developing of the UNIDROIT Principles of International Commercial Contracts. This regulation is an obvious example of advantages that can be achieved by the creative normative process of the most esteemed experts not limited by the political imperative of the states they hail from. Their results achieve success because of the quality of their solutions and by doing so they promote alternative methods of harmonization of international commercial law.
\end{abstract}

Keywords: bottom-up method, harmonization of law, the UNIDROIT Principles of International Commercial Contracts, soft law.

\section{BOTTOM-UP METHOD OF HARMONIZATION OF LAW}

At the international level, theorists have been noting the striking reproduction of "manufacturers" of law, sources of law and privatization of legal regimes". Namely, different law harmonization methods appear in response to the need for

\footnotetext{
${ }^{1}$ Stefan Vogenauer, "Sources of Law and Legal Method in Comparative Law", The Oxford Handbook of Comparative Law (eds. Mathias Reimann, Reinhard Zimmermann), Oxford 2006, 879.
} 
converging national legal orders. In the European Union (hereinafter: the EU), they are implemented in general with primary, and more specifically, with secondary sources of law. On the wider, world level, international conventions prove to be the most effective means of unification. In these cases standard, traditional hard law sources are used with indisputable achievements. However, apart from the obvious advantages, these types of regulations are marked with certain shortcomings, prompting records of the "loss of momentum" 2 of conservative processes of unification of law. First of all, the process of their adoption is burdened by the need to reach a compromise among representatives of different legal systems, directly influencing the possibility of achieving innovative and precise normative solutions. Furthermore, the process of their adoption is often lengthy and administratively, bureaucratically and financially exhausting. Then, once adopted, a convention has to be ratified internally in the state, further extending the period of entry into force, with the constant possibility for the rules set out in it to become obsolete. Moreover, the increasingly complicated situation is contributed by many new international issues (for example, mixed contracts) on which states cannot reach an agreement, nor anticipate the effects of possible incorporation into their own system. Consequently, as a result of the partial overcoming of traditional law creation methods, the unconventional normative role of various international organizations and private bodies becomes stronger. For example, the process of spontaneous unification of international law by professional non-governmental organizations is already recognized as dominant and is also called private unification. Namely, the above factors have made room for more innovative types of legal activity, that is, different ways of achieving the same goals. It is about using relatively new and, from certain doctrinal points of view, controversial soft law instruments ${ }^{3}$ which are the basic way of "normative expression" of the advocates of the so-called bottom-up method of harmonization of law.

Bottom-up or 'from below' method, as an alternative approach to harmonization of law, is based on the activities of international governmental and non-governmental organizations and various non-legislative bodies (groups of legal theoreticians and practitioners) resulting in regulations whose application is only recommended (soft law) but which acquire credibility by justifiability of normative solutions. These are primarily private initiatives, with, as a rule, prominent lawyers standing behind. This is the reason why the names of the most deserving individuals are linked to projects (the most obvious example is Principles of Eu-

\footnotetext{
2 Jurgen Basedow, "The Renascence of Uniform Law: European Contract Law and Its Components", Legal Studies 2/1998, 122.

${ }^{3}$ Soft law sources are a set of non-binding rules of heterogeneous form (principles, model laws, model contracts, recommendations, etc.) that do not arise in the usual legislative processes but produce significant de facto legal effects.
} 
ropean Contract Law - Lando Principles). Such a method implies the freedom of contracting parties and courts to apply such established regulations as chosen law, so it is also called optional. In any case, it is a supranational, non-centralistic, academic method of harmonization of law that is best implemented in the EU. It is also called the non-invasive method, and in relation to the "top-down" method, the distinction imperio rationis and ratione imperii is also used. Therefore, the essence of the bottom-up method is that professional and academic public should, on its own, formulate appropriate formally non-binding legal rules that would eventually gain in authority and be applied in practice. ${ }^{4}$ On the contrary, by topdown (invasive, centralistic) approach, uniform rules should be adopted by the authorities and imposed from the above by threat of sanctions (as is the case with conventions or national laws - hard law regulations).

The representatives of bottom-up method often perform selective harmonization as they are not conditionally required to harmonize entire fields. They also freely choose the highest quality provisions from all possible legal sources as they are not limited by attempts to imitate a law typical of a particular system, ${ }^{5}$ nor are they imposed to achieve maximum democratic compliance with existing national legislations. Thus, they are guided by the most current solutions that will correspond to the practice of businessmen, so by minimizing political constraints, the focus is shifted on the groundness and cost-effectiveness of the proposed provisions. By its content, bottom-up method corresponds to the so-called common core approach, which consists of a comparative analysis of certain systems aimed at determining the existence of similar norms ${ }^{6}$. Nevertheless, on the basis of the better rule approach, experts can also recognize that a more appropriate regulation of an issue is a solution that is specific or less represented, or which is an innovative common view.

Today the academic activity is organized into specific intellectual groups with specific research objectives. ${ }^{7}$ Certainly, the legislative role of legal science, even pretty widely interpreted, is a rather sensitive issue since it is not considered a formal source of law. Nevertheless, its contribution shows that legally usable solutions do not need to necessarily originate solely from an international or national legislative body. Namely, the bottom-up approach, along with soft law sources,

\footnotetext{
${ }^{4}$ Dušan Nikolić, Uvod u sistem građanskog prava, Novi Sad 2008, 76.

${ }^{5}$ This "freedom" in choice of both civil law and common law solutions is observed through the prism of interweaving processes of Americanization and Europeanization of laws.

${ }^{6}$ In this context, the comparative method has gradually evolved from the opposing method to the integration method. Xavier Blanc Jouvan, "Reflections on the Common Core of a European Private Law Project", Global Jurist Frontiers 1/2001, 54.

${ }^{7}$ Examples include Pavia or Gandolfi Group working on the Project of the European Contract Code; The project of Common Core of European Private Law at the Law School in Trent; The European Civil Code project entrusted to the Study Group for the European Civil Code, etc.
} 
corespondes to more spontaneous harmonization of law. Viewed strictly from a political point of view, the acceptance of normative standards in soft law forms can be understood as a recognition that firm state control over the international process of creating law has weakened or that the theory of monism, which considers the state the sole creator of law, is relativized. One thing is for sure - international, national and European Union levels are no longer the only normative possibilities as "the continuing coexistence of laws stems from conservative but also private international regulations."

Furthermore, the complexity of contemporary bottom-up processes of harmonization is noticeable in the case of the so-called new lex mercatoria (soft law in international commercial law). ${ }^{9}$ Namely, it develops at the crossroads of international organizations in the capacity of the so-called formulating agencies (e.g. International Institute for the Unification of Private Law - hereinafter referred to as: UNIDROIT, United Nations Commission on International Trade Law, hereinafter referred to as: UNCITRAL, International Chamber of Commerce, hereinafter referred to as: ICC) ${ }^{10}$ and ad hoc groups and private initiatives. In this way, a kind of autonomous international codification is carried out, expressing the interests of professional and business circles without the need for formal unification. The practice and acceptance of this alternative approach clearly show that the response to the harmonization needs of international commercial law lies in combining the bottom down and bottom-up methods and their hard law and soft law instruments.

Certain soft law acts in international commercial law have justified the bottom-up method to such an extent that it is argued that it is best to leave the formulation of international trade rules of a higher level of abstraction to theoreticians, while the governments (insufficiently motivated to dedicate themselves to projects whose ultimate goal is not a legal operational instrument) should regulate more detailed questions where the rules are mostly compulsory. ${ }^{11}$ Specifically, the UNIDROIT Principles of International Commercial Contracts that will be at the centre of further consideration are deemed the most successful example of this harmonization method.

\footnotetext{
${ }^{8}$ Jan Smits, „The Draft Common Frame of Reference, Methodological Nationalism and the Way Forward“", European Review of Contract Law Vol. 3, 2008, 270.

9 This source of law covers a wide body of rules: UNIDROIT Principles for International Commercial Contracts, Principles of European Contract Law, Model Laws such as Model Law on International Commercial Arbitration and Model Contracts (primarily Geneva General Terms and Conditions and Type Contracts), Incoterms Rules, etc.

${ }^{10}$ Term 'formulating agency' has been used lately for international organizations of importance for the formulation of legislative trade policy.

${ }^{11}$ Jose Angelo Estrella Faria, "Future Directions of Legal Harmonization and Law Reform: Stormy Seas or Prosperous Voyage?”, Uniform Law Review Vol. 14, 1-2/2009,13.
} 


\section{THE DEVELOPMENT AND IMPORTANCE OF THE UNIDROIT PRINCIPLES OF INTERNATIONAL COMMERCIAL CONTRACTS}

UNIDROIT has made a capital contribution to the harmonization of commercial law by adopting the UNIDROIT Principles of International Commercial Contracts (hereinafter: the UNIDROIT Principles). ${ }^{12}$ The preparation of this regulation was delegated to the study group formed by experts in the field of international commercial and contract law from every continent (from civil law and common law systems, and socialist and market economies). The participants acted exclusively in private capacity, without the obligation to represent the interests of their governments, which was the backbone of the applied bottom-up method.

The legal sources of the project were primarily the American Uniform Commercial Code, the Restatement (Second) of the Law of Contracts, the United Nations Convention on Contracts for the International Sale of Goods from 1980 (hereinafter: the Vienna Convention) and the non-legislative international commercial rules (Principles of European Contract Law). It was, precisely, the negative sides of the Vienna Convention (which was, off course, the exceptional bottom down harmonization achievement and the absolute legislative maximum at the moment) that "decided" that UNIDROIT should abandon the idea of a binding instrument and prepare the restatement of international contract law. Moreover, the non-binding nature of the UNIDROIT Principles seemed appealing, not problematic, and informal codification of transnational commercial law was called "the order of the day". ${ }^{13}$ Considering that the UNIDROIT Principles were not intended to face the fate of a hard law instrument, it was possible (in the matter in which the field of application of these two regulations overlaps) to deal with issues not covered by the Convention (authority of agents, hardship, etc.) or which, as a consequence of compromise, needed to be further interpreted (e.g. the principle of good faith). Moreover, in addition to the basic and preferred approach searching for a common core, exceptional rules that were considered the most suitable and did not represent the most common solutions, were adopted through the "better rule approach". The group characterized its work as a functional legal comparison with the aim of creating a harmonized range of rules to be applied worldwide regardless of the legal traditions and economic and political conditions of the countries in which they will be implemented.

The first version of the UNIDROIT Principles was published in 1994. Having enjoyed great success, the conclusion was reached that they should be reworked

12 UNIDROIT Principles of International Commercial Contracts from 2016, https://www. unidroit.org/instruments/commercial-contracts/unidroit-principles-2016, 24 January, 2018.

${ }^{13}$ Klaus Peter Berger, "The Principles of European Contract Law and the Concept of the Creeping Codification of European Contract Law”, European Review of Private Law Vol. 9, 2001, 30. 
and supplemented, so the new version appeared in 2004 (with new chapters on obligation set-off, limitations periods, etc. $)^{14}$. By the third version of the Principles from 2010, the number of provisions increased from 185 to 211 (including rules of invalidity and conditions for concluding contracts and amending provisions regarding termination of contracts, restitution, etc.). The latest version from 2016 only marginally amended six provisions to take into account the specificity of long-term contracts. ${ }^{15}$

By their content, the UNIDROIT Principles relate to fundamental issues regarding international commercial contracts. They represent a transnational, flexible instrument that allows the convergence of national regulations and seeks to prevent the emergence of disputes. They are considered a particularly authoritative expression of the current consensus on international legal rules governing international commercial transactions. They are significant for the process of creating the so-called world traders' law and represent a non-legislative codification of the general part of the international commercial contracts law. Formulation of Article 1.7 of the Principles - the principle of good faith and fair dealing is called the Magna Charta of International Commercial Law, while some theoreticians consider the UNIDROIT principles a new ius commune. ${ }^{16}$ Solutions incorporated in them reflect the essence of modern business dealings. They are one of the most accepted and praised soft law regulations. They are not a rigid and limiting legal source, but leave a lot of room for adaptation; although they are of a dispensable nature, they can be deemed a step of capital importance towards the globalization of legal thinking.

The fact that the UNIDROIT Principles are a product of a group of independent experts who worked under the auspices of an international organization certainly has its own advantages. Not only has this paved the road towards greater discretion in acting, but it also enabled flexibility and quicker harmonization with the changing conditions of international commercial practice. In this regard, there is no fear of unjustified "pretending" to the regulation of a certain legal issue, since the UNIDROIT Principles will be applied only if they prove to be of quality and suitability for a specific situation and its subjects. Finally, UNIDROIT is free to make changes whenever it proves to be necessary or can simply remove those

${ }^{14}$ Dušanka Đurđev, ,Nacrt zajedničkog referentnog okvira za evropsko privatno pravo iz 2009. godine“, Zbornik radova Pravnog fakulteta u Novom Sadu (Zbornik radova PFNS) 2/2010, 69.

${ }^{15}$ Texts of the above versions of the UNIDROIT Principles are available at

https://www.unidroit.org/instruments/commercial-contracts/unidroit-principles-1994; https:// www.unidroit.org/instruments/commercial-contracts/unidroit-principles-2004; https://www.unidroit.org/instruments/commercial-contracts/unidroit-principles-2010; 2018.

https://www.unidroit.org/instruments/commercial-contracts/unidroit-principles-2016, 11 May,

${ }^{16}$ Michael Joachim Bonell, "UNIDROIT Principles and European Principles: Similar Rules for the Same Purpose?”, Uniform Law Review Vol. 2, 1996, 245. 
provisions found to be inadequate for the market, which is why they are already experiencing their fourth edition.

\section{THE UNIDROIT PRINCIPLES OF INTERNATIONAL COMMERCIAL CONTRACTS FIELD OF APPLICATION}

The data of the Center for Transnational Law and the UNILEX database are primarily used for the purpose of globally monitoring the implementation of the possible ways of applying the UNIDROIT Principles envisaged in the Preamble (paragraphs 1-7). Research shows that the UNIDROIT Principles are used in all imagined ways but due to the often contracted confidentiality or explicit non-stating of the UNIDROIT Principles as a source, it is not possible to accurately state how much they are actually used, so it is certain that this scope is even wider than the formally recorded. Given that the UNIDROIT Principles belong to soft law, they are applied on the basis of autonomy of the will. The Model Clauses for the implementation of the UNIDROIT Principles were published in 2013 and by their incorporation, the interested parties can most efficiently benefit from this multifunctional instrument.

\subsection{The UNIDROIT Principles in the function of model law}

The UNIDROIT Principles as model law affect the processes of legal reforms of states still adapting to modern normative standards as well as those with highly developed legal systems. In this capacity, they are shown as an exceptional soft law and bottom-up harmonization achievement.

Thus, for example, the UNIDROIT Principles have been referenced to when drafting the civil codes of the Czech Republic, Estonia, the Canadian province of Quebec, and the new codes of the Russian Federation and the Netherlands. The US Uniform Commercial Code has been revised in order to harmonize its provisions with the UNIDROIT Principles. The French-speaking countries of Africa have prepared their General Commercial Code under the influence of the UNIDROIT Principles. ${ }^{17}$ They were used in the Proposal for reform of the rules on interpreting legal acts published in 1996 by the Scottish Legal Commission, as well as in the Proposal for reform of the general rules on commercial contracts in the Spanish Commercial Code. They served as a modernization model for the contract law of the People's Republic of China, Mongolia, Georgia, Vietnam and as a form used for the adoption of the civil laws of Australia, Lithuania and Hungary. ${ }^{18}$ The German

\footnotetext{
${ }^{17}$ Ivanka Spasić, „UNIDROIT - Doprinos unifikaciji nekih od najvažnijih pitanja međunarodnog trgovinskog prava“, Strani pravni život 2/2009, 33.

${ }^{18}$ Huang Dahan, „The UNIDROIT Principles and their Influence in the Modernisation of Contract Law in the People's Republic of China“, Uniform Law Review Vol. 8, 2003, 107.
} 
Civil Code was partly inspired by the contents of the UNIDROIT Principles, and they were also used during the modernization of contract law in the Organization for Economic Co-operation and Development and the Organization for the Harmonization of Business Law in Africa ${ }^{19}$. Furthermore, the UNIDROIT Principles' provisions regarding the limitation periods were used in 2008 as an inspiration during the reform of the French law on statutes of limitations related to privatelegal relations. Also, the International Chamber of Commerce in Paris created a Model Clause on Hardship, the solutions of which are inspired by the UNIDROIT Principles. They represent a significant reference of legal inspiration in other soft law projects within the EU, such as the Draft Common Frame of Reference for European Private Law ${ }^{20}$ and the Principles of the European Insurance Contract Law.

\subsection{The UNIDROIT Principles as applicable contract law}

The UNIDROIT Principles are a law governing a contract when the parties incorporate them fully or partially into the contract, or when they are designated by the parties in a contractual clause as the law under which the contract is to be implemented and possible disputes are to be resolved. They are most often used in contracts for the international sale of goods, contracts for commercial agency and other forms of distribution and franchising contracts, but also with transport and insurance contracts. ${ }^{21}$ It is certainly easier for parties to use a ready-made source of provisions for their contract. In this way, they save time but also use tried-andtrue provisions created by experts. Also, contracting parties belonging to different legal systems face the problem of different legal terminologies. Using the UNIDROIT Principles, they are enabled to use a legally neutral terminology variant available in all major languages of the world. Furthermore, in the case when two unequal parties negotiate, it is common for a stronger party to impose the choice of law. It can, however, do this in favour of regulating the contract by the UNIDROIT Principles to avoid its unpredictable national law. ${ }^{22}$ Also, for small and medium businesses, the UNIDROIT Principles are particularly appealing as these entities are not usually able to comparatively search through the laws to find the most suitable solution for them, so the UNIDROIT Principles are a significant, neutral and immediately ready set of rules. In this context, businesspeople in Serbia would certainly benefit from a more widespread turning to this instrument.

\footnotetext{
${ }^{19}$ I. Spasić, 33.

${ }^{20}$ D. Đurđev, ,,Soft law u evropskom komunitarnom pravu“, Zbornik radova PFNS 1/2013, 107.

${ }^{21}$ Radovan Vukadinović, Međunarodno poslovno pravo, Kragujevac 2012, 357.

${ }^{22}$ For example, it is stated that „businessmen from Russia consider that the UNIDROIT Principles provide a better, more elaborate and generally accepted regulation of issues relating to business transactions.“ Alexander Komarov, „The Unidroit Principles of International Commercial Contracts: A Russian View“, Uniform Law Review Vol. 1, 1996, 247.
} 


\subsection{The UNIDROIT Principles in proceedings before arbitration tribunals}

Arbitration tribunals apply the UNIDROIT Principles: a) if the parties have specifically referred to their application in the event of a dispute ${ }^{23} \mathrm{~b}$ ) if the parties have agreed to apply general legal principles, lex mercatoria and the like; c) where it is impossible to determine the governing law or the rule of governing law; ${ }^{24}$ d) when they are used as sources of interpretation and supplementation of international uniform regulations.

The UNIDROIT Principles can be applied before arbitration tribunals since the laws of a large number of countries (based on the Model Law on International Commercial Arbitration from 1985) allow the parties to choose "legal rules" and not just the "law" of a country, leaving them to choose to turn to non-national and supranational rules. ${ }^{25}$ Such an example was also followed in Serbia by the Law on Arbitration ${ }^{26}$ and the Rules on Permanent Arbitration at the Serbian Chamber of Commerce. ${ }^{27}$

It should be emphasized that arbitrators at the international level use the UNIDROIT Principles as an expression of general legal principles and lex mercatoria $^{28}$ to a significant extent, and future use will show whether they will firmly establish themselves as their best and most comprehensive expression. In any case, the practice pursued by arbitrators is an important indicator of the extent to which this soft law act is accepted by the business community as a manifestation of its general principles.

\subsection{The UNIDROIT Principles as a means of interpreting and filling the voids of an international uniform law}

Contracting parties may explicitly agree upon subsidiary application of the UNIDROIT Principles. ${ }^{29}$ On the other hand, arbitrators are referring to their pro-

\footnotetext{
${ }^{23}$ For example, Arbitration Court of the Lausanne Chamber of Commerce and Industry, http://www.unilex.info/case.cfm?id=863, 23 January 2018.

${ }^{24}$ For example, the International Commercial Arbitration at the ICC decided to apply the provisions of Art. 4.1-4.3. of the UNIDROIT Principles to a contract whose applicable law was not determined and which had insufficiently strong links with the jurisdictions of Tanzania, France, Bermuda and Rwanda (ICC International Court of Arbitration No. 11265, 2003).

25 The first laws that envisaged such an option were the laws of France, Switzerland and England.

${ }^{26}$ Zakon o arbitraži, Službeni glasnik Republike Srbije, br. 46/2006, čl. 50.

${ }^{27}$ Pravilnik o Stalnoj arbitraži pri Privrednoj komori Srbije, Službeni glasnik Republike Srbije, br. 101/2016, čl. 42, st. 1 .

${ }^{28}$ For example. Ad hoc arbitration San José, Costa Rica, 30/04/2001, http://www.unilex. info/case.cfm?id=1100 21 February, 2018.

${ }^{29}$ For example, ICC International Court of Arbitration no. 12460, 2004.
} 
visions most often to fill in the legal gaps that exist in the Vienna Convention (which, for example, relate to the determination of interest rates, hardship, etc.). ${ }^{30}$ A representative example of such a use is the case brought before the Belgian Court of Cassation between a Dutch and French company regarding the sale of steel pipes on the basis of a contract regulated by the Vienna Convention. Considering that it did not explicitly regulate the issue of hardship, pursuant to Art. 6.2.2 of the UNIDROIT Principles, it was decided to approve the seller's request to renegotiate the price due to an increase in the price of goods in the amount of 70 per cent. ${ }^{31}$ Similarly, the UNIDROIT Principles were used in a dispute concerning a contract regulated by the Vienna Convention as a normative framework and evidence of the existence of international practice regarding penalty payment due to late payment of the price (which is a subject not covered by the Vienna Convention). ${ }^{32}$

Regarding the interpretation of the Vienna Convention using the UNIDROIT Principles, the greatest number of cases relate to the issue of good faith or the issues regarding which losses, in addition to loss of profit, are recoverable (for example, pursuant to Article 7.4.2 of the UNIDROIT Principles, damage includes any loss suffered and any benefit the damaged party was deprived of, that is, the principle of full compensation for damages is adopted). Article 7 of the Vienna Convention sets out three principles that must be respected in interpreting the Convention: promoting uniformity, respect for international character and respect for good faith and fairness in international trade. Theoreticians guided by these criteria justify the use of the UNIDROIT Principles in this context by the fact that they are the result of a comparative analysis and broad international discussion and that they are adapted to the needs of disputes arising from international commercial contracts to a greater extent than any particular national legal system. ${ }^{33}$

Certainly important is the position of arbitrators who applied the relevant provisions of the UNIDROIT Principles in a dominant number of situations for the sake of interpreting or filling legal gaps without any reasoning ${ }^{34}$ or because they consider them "one of the general principles under Art. 7. para. 2 of the Vienna Convention". ${ }^{35}$ There is even a recorded situation in which the arbitration tribunal stated it would "apply the general principles now contained in the UNIDROIT

\footnotetext{
30 Jelena Vilus, „Načela međunardnih trgovinskih ugovora“, Pravni život 11/1998, 415.

${ }^{31}$ Court of Cassation of Belgium, Scafom International BV vs Lorraine Tubes s.a.s., no. C.07.0289.N, Belgium, 19/06/2009.

${ }^{32}$ International Arbitration Court of the Chamber of Commerce and Industry of the Russian Federation, no. 229/1996,http://www.unilex.info/case.cfm?id=669, 21 October 2017.

${ }^{33}$ Ole Lando, „The Principles of European Contract Law and the lex mercatoria“, Private Law in the International Arena (ed. J. Basedow), Hague 2000, 396.

${ }^{34}$ ICC Award No. 8769 of December 1996, ICC International Court of Arbitration Bulletin, 75.

${ }^{35}$ ICC Award No. 8128 of 1995, Journal de droit international, 1996, 1024.
} 
Principles" 36 or that "when applying the Vienna Convention it is of informative significance to turn to the UNIDROIT Principles as they represent a globally reached consensus on the most fundamental issues of contract law" ${ }^{37}$ It is precisely the Vienna Convention that is negatively referred to as "being a convention that for some issues codifies the agreement that there is no agreement ${ }^{38}$, and even that "although it is a binding law, the Vienna Convention should be regarded as soft law." 39

Still, the question of such a use of the UNIDROIT Principles is very delicate since, in addition to being soft law regulation, they are also regulation that came into existence after the Vienna Convention. However, in our opinion, there is no reason to ignore these use values of theirs as the UNIDROIT Principles are made analogously to this Convention and allowing for its shortcomings arising from the normative solutions of compromise character (in which case the provisions need to be further interpreted) or complete avoidance of the regulation of a legal issue due to the inability to reach a consensus (in which case it is necessary to fill in a legal gap). In addition to being an expression of fundamental principles of international contract commercial law accepted by the academic and business community, a valid basis for their application may be, first and foremost, a contractually expressed commitment of the parties to this regulation as an instrument used for interpreting provisions and/or filling gaps (in the case of regular application of contractual provisions and/or court/arbitration dispute). In practice, it has been shown that both domestic courts and arbitration tribunals have a highly favourable attitude towards this purpose of the UNIDROIT Principles, thus setting an excellent example of the complementary use of the top down and bottom up regulations.

\subsection{Application of the UNIDROIT Principles by national courts}

The UNIDROIT Principles are applied before national courts only in so far as they do not contravene the binding norms of the applicable law. However, there is a possibility that such treatment may be changed in the future..$^{40}$ Expectedly, UNIDROIT expresses strong support for this initiative, as it would provide the possibility of finding a neutral option focused on the special aspects of international business. Certainly, it is again a questionable use of the UNIDROIT Principles, which should, by some, be avoided by simple application of lex fori, but on the

${ }^{36}$ ICC Award No. 8817 of December 1997, International Court of Arbitration Bulletin, 75-78.

${ }^{37}$ ICC Award No. 9117 of March 1998, International Court of Arbitration Bulletin, 96-101.

${ }^{38}$ Joseph Loofkofsky, "Loose Ends and Contorts in International Sales: Problems in the Harmonization of Private Law Rules", The American Journal of Comparative Law 2/1991, 404.

${ }^{39}$ Larry DiMatteo, International Sales Law: A Global Chalenge, Cambridge 2013, 11.

40 The US Uniform Commercial Code envisages the possibility for parties to agree on the implementation of the UNIDROIT Principles, while in the EU there is a similar Commission's initiative expressed in the Green paper on the conversion of the Rome Convention of 1980. 
other hand theorists advocate this application of the UNIDROIT Principles by "calling on the courts to renounce the trend of insisting on the application of domestic law in favor of a solution providing both an internationally accepted standard and an exceptional level of legal certainty." ${ }^{\text {"1 }}$ Certainly, it is not likely that judges will soon give up the focus on their national systems, for the simple reason of being familiar with them.

However, the role that the UNIDROIT Principles may have in the context of interpreting and supplementing the principles of domestic law relevant for the contract is very important. This function of the UNIDROIT Principles has become widely recognized as the function of restatement. For example, it is stated that the UNIDROIT Principles are useful since national rules can prove to be too rigid for the context of international contracts, or that by using them the gap between domestic legal systems and lex mercatoria can be overcome. ${ }^{42}$ Certainly, in our opinion, at least informal consulting of this soft law instrument can be implied for the above purposes.

A significant indication is, undoubtedly, the fact that in the quite a number of cases $^{43}$ of their use, the UNIDROIT Principles were intended to interpret the domestic law and prove whether it is consistent with internationally accepted standards. Also, it should be noted that the interpretation and supplementation of individual national laws largely concerned the laws of England, Australia, France, Italy, the Netherlands and Switzerland, which confirms that even highly sophisticated legal systems do not always provide satisfactory answers to the needs of modern commercial transactions. In any case, this function of the UNIDROIT Principles in theory ${ }^{44}$ is considered even more important than their role as the applicable contract law. And indeed, as restatements in the US practice, the UNIDROIT Principles are, by their very nature, the most appropriate to serve as a legal background for the application of domestic law in an international context, and as such can over time become a certain form of ius commune or general part of international contract law.

\section{CONCLUSION}

The UNIDROIT Principles represent an exceptional harmonizing fruition achieved through the use of bottom-up method. The quality of the solutions pre-

\footnotetext{
${ }^{41}$ J. Basedow, "Germany", A New Approach to International Commercial Contracts (ed. M. J. Bonell), London 1999, 147.

${ }^{42}$ K. P. Berger, The Creeping Codification of the Lex Mercatoria, London 1999, 184.

${ }^{43}$ For example. ICC International Court of Arbitration, no. 11869, 1998; then ICC International Court of Arbitration - Brussels no. 8240, 1995.

${ }^{44}$ M. J. Bonell, "The UNIDROIT Principles 2010: An International Restatement of Contract Law”, Uniform Law Review 2/2011, 24.
} 
sented by this instrument is proved by their wide and multiple use in international commercial practice: as model laws for national laws, as the law governing contracts, in proceedings before courts and arbitration tribunals, and as a means of interpreting and supplementing uniform regulations. Furthermore, the importance of this soft law regulation is such that the academic community promotes the directions of its further development in the form of: 1) the UNCITRAL's convention on the general part of contract law; 2) formal usage of the UNIDROIT Principles as a means of interpreting and supplementing the Vienna Convention - by the UNCITRAL's recommendation; 3) formal acknowledgement of the right of parties to choose the UNIDROIT Principles as the law governing the contract and a means for mediation or conciliation; 4) the adoption of the UNIDROIT Principles as a model law in the narrower sense. ${ }^{45}$

Such serious effects and perspective of the UNIDROIT Principles are seen as the result of an innovative form of harmonization of law. Namely, the backbone of the applied bottom-up method of law harmonization implied the release of the experts involved in the process of work on this regulation from political directives - they performed in private capacity. This has achieved objectivity in assessing the best normative solutions from both civil law and common law systems, but also in the introduction of novelties. Thus, the regulation is made that plays a more proactive rather than a reflexive role, whose main advantages are currency, flexibility, and the so-called plasticity. Namely, this is a highly efficient means adaptable to the quickly changing economic needs, as evidenced by the fact that in 2016 it was issued in its fourth edition. The legal doctrine finds that this soft law instrument is successful precisely due to the fact that it is not binding, does not represent a threat to national legal systems, but is rather a regulation appropriate for the practice of businessmen and not requiring any special formalities. With its help, harmonization is carried out in an unobtrusive, innovative and contemporary manner. The example of the relationship of the Vienna Convention and the UNIDROIT Principles is an important argument in favour of the use of the alternative bottom-up method as an approach complementary to the traditional bottom down aspects of harmonization of law.

${ }^{45}$ O. Lando, „Principles of European Contract Law and Unidroit Principles: Moving form Harmonisation to Unification?", Uniform Law Review Vol. 11, 2003, 123. 
Др Марија Д. Мијайовић, адвокайски ирриирравник mrksicmarija@gmail.com

\section{Актуелност принципа UNIDROIT за међународне трговинске уговоре - ефекти bottom-up метода хармонизације права}

Сажетиак: Приниийи UNIDROIT за међународне тирг̄овинске уг̄оворе недавно су издатии у свом четиврииом издаюу иито је йовод за анализу йорекла великог усиехх овог̄ вищенаменског̄ инстируменйа. Наиме, овај soft law йройис, иако формално необавезујућ има значајне de facto иравне ефекиее: модел закон је многим ирравним систетемма, корисиии се као меродавно уг̄оворно

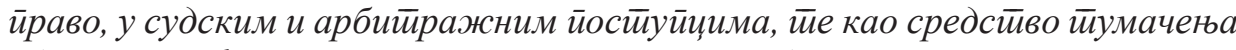
и дойуне униформних инсиируменайа. У овом раду йосмайрана је улог̄а иизв. bottom-ир ирристиуйа као академског, несанкиионисаног̄, „одоздо“ метиода хармонизаиије ирава чијом ирименом су Принцийи UNIDROIT за међународ-

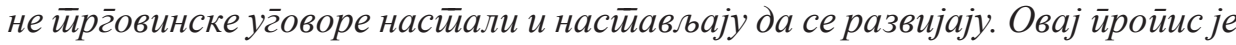

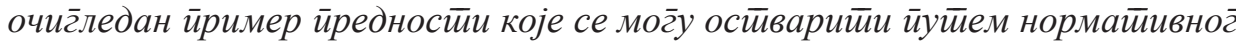
стиваралачког йроцеса најиризнатиијих стиручњака који у свом раду нису огрраничени иолитиичком вољом инстиитучија држава из којих долазе, йе чији

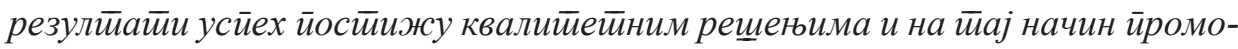

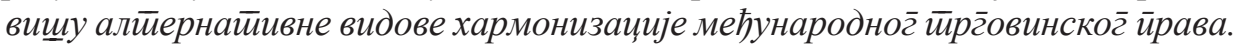

Кључне речи: bottom-ир мет̄од, хармонизачија йрава, Принцийи UNIDROIT за међународне йрг̄овинске уг̃оворе, soft law.

Датум пријема рада: 02.04.2018. 